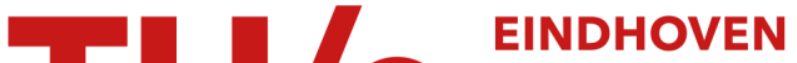 UNIVERSITY OF TECHNOLOGY
}

\section{The mechanism of the copper ion catalyzed autoxidation of cysteine in alkaline medium}

\section{Citation for published version (APA):}

Zwart, J., Wolput, van, J. H. M. C., \& Koningsberger, D. C. (1981). The mechanism of the copper ion catalyzed autoxidation of cysteine in alkaline medium. Journal of Molecular Catalysis, 12(1), 85-101.

https://doi.org/10.1016/0304-5102(81)80021-1

DOI:

10.1016/0304-5102(81)80021-1

Document status and date:

Published: 01/01/1981

\section{Document Version:}

Publisher's PDF, also known as Version of Record (includes final page, issue and volume numbers)

\section{Please check the document version of this publication:}

- A submitted manuscript is the version of the article upon submission and before peer-review. There can be important differences between the submitted version and the official published version of record. People interested in the research are advised to contact the author for the final version of the publication, or visit the $\mathrm{DOI}$ to the publisher's website.

- The final author version and the galley proof are versions of the publication after peer review.

- The final published version features the final layout of the paper including the volume, issue and page numbers.

Link to publication

\section{General rights}

Copyright and moral rights for the publications made accessible in the public portal are retained by the authors and/or other copyright owners and it is a condition of accessing publications that users recognise and abide by the legal requirements associated with these rights.

- Users may download and print one copy of any publication from the public portal for the purpose of private study or research.

- You may not further distribute the material or use it for any profit-making activity or commercial gain

- You may freely distribute the URL identifying the publication in the public portal.

If the publication is distributed under the terms of Article 25fa of the Dutch Copyright Act, indicated by the "Taverne" license above, please follow below link for the End User Agreement:

www.tue.nl/taverne

Take down policy

If you believe that this document breaches copyright please contact us at:

openaccess@tue.nl

providing details and we will investigate your claim. 
() Elsevier Sequoin S.A., Lauganne - Printed in the Netherlands

\section{THE MECHANISM OF THE COPPER ION CATALYZED AUTOXI- DATION OF CYSTENE IN AEKALINE MEDIUM}

J. ZWART, J. H. M. C. VAN WOTPUT and D. C. KONLNGSBERGER*

Laboratory for Inorganic Chemistry, Eindhoven University of Technology, Eirdhoven (The Netherlands)

(Recelped Norember 4, 1980)

\section{Summary}

Quantitative es.r. measurements carried out during the copper caialysed alkaline autoxidation of cysteine show that the Cu(II)-dicysteine complex represents almost the total amount of copper. Only a small fraction ( $<2 \%$ ) of the copper ions might be present in a state which is not detectable by e.s.

The kinetics of the catalytic reaction obeys the rate expression

$$
r_{\mathrm{O}_{2}}=k_{1}\left[\mathrm{O}_{2}\right]^{1 / 2}[\mathrm{Cu}]+k_{\mathrm{K}}\left[\mathrm{O}_{2}\right]^{1 / 2}[\mathrm{Cu}]^{2} \text {. }
$$

The results cannot be explained by a simple $\mathrm{Cu}(\mathrm{II}) / \mathrm{Cu}(\mathrm{I})$ redox mechanisrr.

Instead, a reaction model is proposed, which is based upon the involvement of $a$ thiyl- and a superoxo-activated Cu(II) complex, respectively. These two types of complexes are operative in a chainlike propagation cycle.

\section{Introduction}

The autoxidation of thiols catalysed by copper ions has been investigated by many authors [ 1 - 7]. The overall reaction has been described : 1 , 21 by:

$$
4 \mathrm{RSH}+\mathrm{O}_{2} \longrightarrow 2 \mathrm{RSSR}+2 \mathrm{H}_{2} \mathrm{O}
$$

This reaction is of technological interest to the petroleum industry (sweetening process). Further insight into the mechanism of this reaction might lead to a tetter understanding of the nature of the interaction of oxygen with the active sites of copper-containing proteins: hemocyanine [8], the blue proteins such as ceruloplasmin [9, 101 , ascorbate oxidase, laccase $[11,121$ and cytochrome oxidase [13] :

*Aathor to whom correspondence ahould be addressed. 
Widely accepted features of the mechanism of the copper ion catalysed autoxidation of thiols are:

(i) the catalytic action of copper is based on a $\mathrm{Cu}(\mathrm{II}) / \mathrm{Cu}(\mathrm{I})$ redox couple,

(ii) the only function of oxygen is reosidation of $\mathrm{Cu}(\mathrm{I})$,

(iii) free thiyl and superoxide radicals are assumed to occur as intermediates.

In Farticular, the aikaline copper catalysed oxidation of cysteine to cystine by molecular oxygen was investigated by Cavallini et al. [3] . From stoichiometric determinations, u.y./vis spectrophotometric, and e.s.r. measurements they concluded that a monomeric $\mathrm{Cu}(\mathrm{II})$-dicysteine complex represents the catalytic intermediate. They introduced a $\mathrm{Cu}(\mathrm{II}) / \mathrm{Cu}(\mathrm{I})$ redox cycle with the reduction as the rate determining step, the oxidised cysteine molecule leaving the complex in the form of a thiyl radical. Hanaki and Kamide [5 - 7] also described the cysteine oxidation in the $\mathrm{pH}$ range 7 8.5 in terms of a $\mathrm{Cu}(\mathrm{II}) / \mathrm{Cu}(\mathrm{I})$ couple with thiyl and superoxide radicals as intermediates. Until now, no experimental evidence has been presented in the literature supporting the hypothesis of a $\mathrm{Cu}(\mathrm{II}) / \mathrm{Cu}$ (I) redox cycle, nor has the presence of free radical intermediates during the catalytic reaction really been proved.

Both Cavallini [4] and Hanaki [5, 6] reported on the production and accumulation of $\mathrm{H}_{2} \mathrm{O}_{2}$ during the exidation process in a qualitative way. In a previous publication [14] the $\mathrm{H}_{2} \mathrm{C}_{2}$ production during the autoxidation of cysteine was investigated quantitatively. It was found that the reaction between cysteine (RSH) and oxyeen can be actuallv represented by:

$$
4 \mathrm{RS}^{-}+(1+\alpha) \mathrm{O}_{2}+2 \mathrm{H}_{2} \mathrm{O} \rightarrow 2 \mathrm{RSSR}+2(2-\alpha) \mathrm{OH}^{-}+2 \alpha \mathrm{HO}_{2}^{-}
$$

with $0<\alpha<1$. In all cases the experimentally found relation between $\mathrm{O}_{2}$ consumption and $\mathrm{H}_{2} \mathrm{O}_{4}$ production according to eqn. (2) points unambiguously to the formation of disulfide (RSSR) as the only product of oxidation of cysteine.

In this paper the kinetics of the copper catalysed autoxidation of cysteine in alkaline medium will be investigated in more detail. In particular, the order with respect to oxygen can give decisive information concerning the type of mechanism of the ozidation reaction. The amount of $\mathrm{Cu}$ (II) present during the catalytic reaction has been determined by performine quantitative e.s. measurements. A definitive conclusion concerning the hypothesis of a $\mathrm{Cu}(\mathrm{II}) / \mathrm{Cu}(\mathrm{I})$ redox cycle has been obtained. An attempt will be made to develop a model for the copper catalysed oxidation process at high $\mathrm{pH}$ values. Altemative reaction models will be discussed in the light of the kinetic results and other data as presented in this paper.

\section{Experinsental}

\section{Chemicals}

Cysteine (Merck art. 2838) and histidine (Merck art. 4351) were used without further purification. Copper solutions were made from $\mathrm{CuSO}_{4}$. 
$5 \mathrm{H}_{2} \mathrm{O}$ p.a. (Merck art. 2790). All experiments were carried out at room temperature on solutions with final concentrations of $0.25 \mathrm{~N} \mathrm{NaOH}$ (Merck art. 6482) in de-ionised water.

\section{U.V./VIS and e.s.r. apparatus}

E.S.R. measurements were performed on a Varian E-15 X-band spectrometer with a Scanco $S \mathbf{8 0 8}$ rapid mixing cell. A helium flow cryostat (Oxford Instruments) was used for measuring down to liquid heiium temperature.

U.V./VIS absorption measurements were carried out on a Unicam SP800 spectrophotometer using fused silica rapid-mixing cuvettes.

\section{Liquid recirculation experiments}

In situ u.v./vis and e.s.r. measurements were carried out in a liquid recirculation system connected to the Warburg type apparatus (see below). The reaction liquid was pumped from the reactor through the spectrophotometric and e.s. cells, respectively. The flow rate was sufficiently high to avoid oxygen depletion in the cell.

\section{Rapid-mixing and stopped flow experiments}

In u.v./vis and e.s.r. rapid mixing and stopped flow experiments alkaline solutions of cysteine were mixed with aqueous $\mathrm{CuSO}_{4}$ solutions, resulting in a mixture svith final concentration of $0.25 \mathrm{~N} \mathrm{NaOH}$. Both solutions were degassed and flushed with nitrogen before mising.

\section{Warburg type apparatus}

The kinetic experiments were performed in a Warburg type apparalus, specially cesigned to operate in a range of oxygen pressures from 50 to 800 Torr. The pressure in the reference vessel of the water-filled U-type manometer could be set to the desired value. Since the accuracy of the measurements at low oxygen pressures is strongly dependent on the leak-in of external gas, special care was taken to avoid any leakage.

A stirrer was designed to ensure an uptake of oxygen without diffusional limitation, i.e., oxygen from the gas phase was transported via the inside of the stirrer and subsequently blown into the solution. During all experiments the rate of stirring was set to $3000 \mathrm{rpm}$.

The oxygen pressure was maintained constant automatically by supply of water in a gas buret, thus compensating the uptake of oxygen by the solution. The apparatus was equipped with a $\mathrm{Y}-\mathrm{t}$ recorder to record the oxygen consumption. The kinetic experiments were carried out at $23^{\circ} \mathrm{C}$.

\section{Procedure}

Prior to the start of the experiments all solutions pere degassed by evacuation during a period of 5 - 10 min under vigorous stirring. The oxygen gas in the reference vessel of the manometer was saturated with water and set to the appropriate pressure. The oxygen pressure in the reactor was 
slowly brought to the desired value, after which the recording of the oxygen consumption was started. In the course of an oxidation experiment, the rate of oxygen consumption was determined five times in the region of inearity (i.e. , up to $50 \%$ conversion). Fach experiment was repeated several times. The ultimate value for the rate of oxygen consumption was found by averaging between the mean values of the separate experiments.

\section{Results}

The u.v. and e.s.r. spectra of the copper-dicysieine complex

The optical spectrum, obtained during the oxidation of cysteine ( $\mathrm{RS}^{-}$) catalysed by a solution of copper(II) sulfate, was recorded during liquid recirculation experiments. The spectrum (Fig. 1) has been ascribed to a $\mathrm{Cu}^{\mathrm{II}}\left(\mathrm{RS}^{-}\right)_{2}$ complex [3] . The opticai spectrum proves to be identical with the spectrum recorded during rapid mixing experiments carried out in the absence of oxygen.

The e.s. spectrum reconded under the same circumstances is given ir Fig. 2. This spectrum proves to be the same both under oxidation conditions and in the absence of oxygen. The four line splitting is due to the interaction of the unpaired eleciron with the copper nucleus $\left(a_{\mathrm{av}}^{\mathrm{Cu}}=36.5 \mathrm{G}\right)$. The decrease of the line width of each of the four lines with increasing magnetic field is caused by slow iumbling of the complex [16]. The high field peaks of the copper-cysteine spectrum show an additional splitting in at least five lines. This might be caused by an interaction with at least two equivalent ${ }^{14} \mathrm{~N}$ ligands $\left(a_{\mathrm{av}}^{\mathrm{N}}=10.5 \mathrm{G}\right)$.

Complications in the ligand hyperfine structure may be caused by the two copper isotopes ${ }^{63} \mathrm{Cu}$ and ${ }^{65} \mathrm{Cu}$. No e.s. absorption was detected at $g=4\left(\Delta M_{s}=2\right)$, where signals of magnetically coupled Cu species are to be expected. The temperature dependence of the esI. spectrum, obtained from a sample which was quenched from the reaction liquid, is characteristic for a Curie behaviour down to $4.2 \mathrm{~K}$.

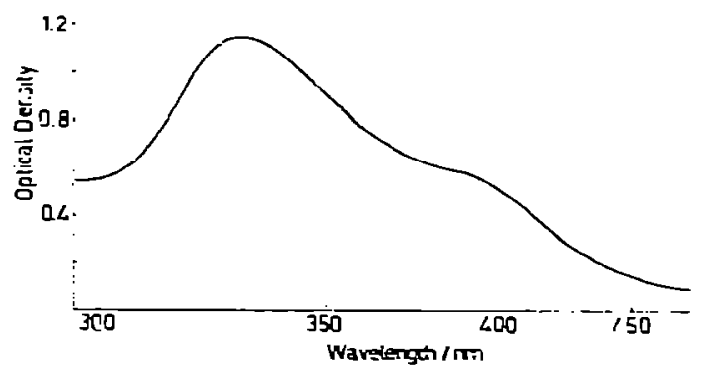

Fig. 1. The optical spectium of $\mathrm{Cu}^{\square}\left(\mathrm{RS}^{-}\right)_{2}$, resorded in the recirculation system during oxidation. [Cu] $=1.85 \times 10^{-4} \mathrm{M} ;[\text { cysteine }]_{0}=14.4 \times 10^{-3} \mathrm{M} ;[\mathrm{NaOH}]=0.25 \mathrm{M}$. Light path: $1 \mathrm{~cm}$ 


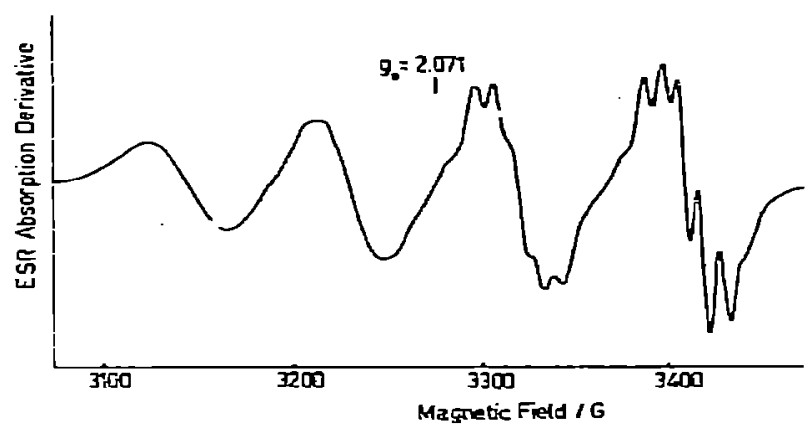

Fig. 2. The ess. spectrum of $\mathrm{Cu}^{\mathrm{I}}\left(\mathrm{RS}^{-}\right)_{2}$, recorded in the recirculation system during oxidation. [Cu] $=2 \times 10^{-4} \mathrm{M} ;[\mathrm{NaOH}]=0.25 \mathrm{M} ;[\text { cysteine }]_{0}=8.25 \times 20^{-2} \mathrm{M}$.

\section{Quantitative e.s.r. measurements}

The problems occurring in determining the intensity of e.s.r. sfectra have been discussed by many authors $[17,18]$. The most important problem is the sample and sample holder-dependent sensitivity of the e.s.r. spectrometer. To avoid these difinculties care was taken that the position of the liquid-cell remained unchanged during all experiments. The spectrum of Cu(II)-dihistidine (intensity normalized to 100 ) was chosen as reference. Experiments were performed in order to investigate the influence of histidine, cysteine, and cystine on the quality factor of the cavity. As can be concluded from the results in Table 1, various amounts of these compounds had no appreciable influence on the quality factor. The spectra were ciouble integrated [19] in steps of 4 Gauss over a scan range of 1000 Gauss.

The spectra under catalytic conditions vere obtained by addinE cysteine powder to the $\mathrm{Cu}$-histidine solution on $0.25 \mathrm{~N} \mathrm{NaOH}$ and stirring

TABEE 1

The intensities of the es.r. spectra of Cu(II)-dihistidine and Cu(II)-dicysteine under different circumstances

\begin{tabular}{|c|c|c|c|c|c|}
\hline $\begin{array}{l}\text { Exp. } \\
\text { no. }\end{array}$ & $\begin{array}{l}{[\mathrm{Cu}] \times 10^{4}} \\
\left.(\mathrm{~mol} \mathrm{l})^{-1}\right)\end{array}$ & $\begin{array}{l}{\left[\text { histidine] } \times 10^{2}\right.} \\
(\mathrm{mol} \mathrm{l}\end{array}$ & $\begin{array}{l}\text { [cysteine ]o } \times 10^{2} \\
\left(\mathrm{~mol} \mathrm{l} \mathrm{l}^{-1}\right]\end{array}$ & $\begin{array}{l}{\left[\text { cystine] } \times 10^{2}\right.} \\
\left(\mathrm{mol} \mathrm{l}^{-1}\right)\end{array}$ & $\begin{array}{l}\text { Inter.sity } \\
\text { (rel. units) }\end{array}$ \\
\hline $\begin{array}{l}1 \\
2 \\
3 \\
4\end{array}$ & $\begin{array}{l}2.0 \\
2.0 \\
2.0 \\
2.0\end{array}$ & $\begin{array}{l}0.19 \\
0.19 \\
0.19 \\
8.44^{c}\end{array}$ & $\begin{array}{l}0 \\
8.25 \\
8.25 \\
0\end{array}$ & $\begin{array}{l}0 \\
0 \\
4.13 \\
0\end{array}$ & $\begin{aligned} 100^{a} & \\
100 & \pm 2^{b} \\
101 & \pm 2 \\
99 & \pm 2\end{aligned}$ \\
\hline
\end{tabular}

In all experiments [NaOH] $=0.25 \mathrm{M}$. In experiments 2 and 3, care was taken that no oxygen limitation occurred.

${ }^{a}$ Intensity normaiized to 100 , representing all added copper.

bI one oxidation run, the spectrum was recorded four times in succession, resulting in four identical spectra.

${ }^{c}$ The afditional amount of bistidine is equal to the initial amount of cysteine in experiment 2. 
vigorously under cxygen atmosphere. The spectrum of $\mathbf{C u}(\mathrm{II})$-dihistidine disappears comp?etely and the spectrom of $\mathrm{Cu}(\Pi)$-cysteine appears immediately after mixing. The presence of histidine neither influences this spectrum, nor the oxygen consumption rate of the catalytic system. Four spectra were recorded in succession during the same oxidation run, i.e., under changing cysteine and cystine concentration. The averaged integrated intensity is given in Table 1, experiment 2. The e.s.r. intensities of both copper-histidine and copper-cysteine were found to be linear in the copper concentration in the range of measurement, viz., $10^{-4}-10^{-1} \mathrm{~mol} \mathrm{l}^{-1}$.

Since none of the reagents affected the quality factor of the cavity, and the geometry of the system inside the e.s. cavity zemained unchanged during all the experiments, the accuracy in determinirig the relative intensities of the spectra can be derived from Table 1 ; it amounts to $2 \%$.

\section{Anaerobic reduction}

The anaerobic reduction of the $\mathrm{Cu}^{\mathrm{II}}\left(\mathrm{RS}^{-}\right)_{2}$ complex was investigated by stopped flow experiments. The decay of both the intensity of the $330 \mathrm{~nm}$ adsorption peak and the magnitude of the high field peak of the e.s. spectrum were menitored after stopping the flow during a rapid mixing experiment performed under anaerobic conditions. The decay, ascribed to reduction of the $\mathrm{Cu}$ (II) complex, was found to be second order with respect to the complex concentration over a range of two orders of magnitude. The anaerobic reduction might therefore be described by:

$$
2 \mathrm{Cu}^{\mathrm{II}}\left(\mathrm{RS}^{-}\right)_{2} \stackrel{k_{20}}{\longrightarrow} 2 \mathrm{Cu}^{\mathrm{I}} \mathrm{RS}^{-}+\mathrm{RSSR}
$$

where the nature of the $\mathrm{Cu}(\mathrm{I})$ complex remains to be studied.

There is a slight but systematic difference between the mean $k_{\mathrm{an}}$ values obtained from optical and e.s.r. decay curves respectively (see Table 2). To investigate if ligh $t$ might be the reason for this, the e.s.r. rapid-mixing cell was irradiated wich u.v. during the decay exgeriments. It was found, indeed, that u.v. irradiation accelerated the anaerobic reduction up to four times depending on the radiation intensity. Therefore, it may be concluded that the low power light beam of the u.v./vis spectrometer slightly inereases the reduction rate of the complex.

\section{Kinetics}

\section{Order with respect to cysteine}

The rate of oxidation proved to be constant up to 50\% conversion. The minor increase of the rate observed at higher conversion might be attributed to a small rise of the $\mathrm{pH}$ value in the course of the reaction. It was demonstrated previously [14] that only a slight increase of the reaction rate could be detecteci when raising tine initial amount of cysteine. Hence, in a first approximation, one can conclude the kinetics to be zero onder with respect to cysteine. 


\section{TABLE 2}

Second order rate constant of anaerobic reduction of Cu(II)-cysteine complex, determined with optical absorption and e.s.x. techniques

\begin{tabular}{|c|c|c|c|}
\hline \multirow{2}{*}{$\begin{array}{l}{[\mathrm{Cu}] \times 10^{4}} \\
\left(\mathrm{~mol} 1^{-1}\right)\end{array}$} & \multirow{2}{*}{$\begin{array}{l}\text { [cysteine ]o } \times 10^{2} \\
\left(\mathrm{~mol} \mathrm{l}^{-1}\right)\end{array}$} & \multicolumn{2}{|c|}{$k_{3 n}\left(\mathrm{~mol}^{-1} 15^{-1}\right)$} \\
\hline & & uvivis & e.s.r. \\
\hline $\begin{array}{c}1.0^{\mathrm{a}} \\
2.0^{\mathrm{b}} \\
4.0^{\mathrm{c}} \\
4.0 \\
4.0 \\
20 \\
100\end{array}$ & $\begin{array}{l}1.0 \\
0.5 \\
4.0 \\
4.0 \\
4.0 \\
4.0 \\
5.0\end{array}$ & $\begin{array}{l}68 \\
68 \\
63 \\
58\end{array}$ & $\begin{array}{l}53 \\
54 \\
56 \\
54 \\
58\end{array}$ \\
\hline & & $\bar{k}_{\mathrm{an}}=64 \pm 5$ & $\bar{k}_{\text {an }}=55 \pm 2$ \\
\hline
\end{tabular}

In all experiments [ $\mathrm{NaOH}]=0.25 \mathrm{M}$. Light-patb : a: $2 \mathrm{~cm} ; b: 1 \mathrm{~cm} ; c: 0.5 \mathrm{~cm}$.

Order with respect to oxygen

The rate of oxygen consumption diring the catalytic process was measured as a function of the oxygen pressure at three different copper concentrations (see Fig. 3).

To find out which type of hinetics fits the data, two relevant kinetic expressions were tested:

$$
\begin{aligned}
& \left(r_{\mathrm{O}_{2}}\right)^{-1}=A+B\left(P_{\mathrm{O}_{2}}\right)^{-1} \\
& r_{\mathrm{O}_{2}}=k_{1}\left(P_{\mathrm{O}_{2}}\right)^{x} .
\end{aligned}
$$

Equation (4) represents a Lineweaver-Burk plot derived from MichaelisMenten kinetics. By means of linear regression the constants $A, B, k_{1}$ and $x$ were calculated (see Table 3). The curves according to eqns. (4) and (5) using the numerical values of the constants as presented in Table 3 , are shown in Fig. 3 together with the experimental data. It is obvious that the curve derived from Michaelis-Menten kinetics (eqn. (4)) deviates appreciably from the experimental data, taking into account the standard deviation. Therefore, it can be concluded that Michaelis-Menten kinetics is not a good model to explain the kinetics. On the other hand, a satisfactory fit according to eqn. (5) has been obtained.

The values for $x$ are close to 0.5 and suggest that the kinetics with respect to oxygen can be represented by:

$$
r_{\mathrm{O}_{2}}=k_{2}\left(P_{\mathrm{O}_{3}}\right)^{0.5} \text {. }
$$

Straight lines calculated by linear regression appeared to give an excellent fit to the experimental data. (Fig. 4, values of $k_{2}$ are quoted in Table 3). Therefore, it can be inferred from our measurements that the order with respect to oxygen is $\mathbf{0 . 5}$. 


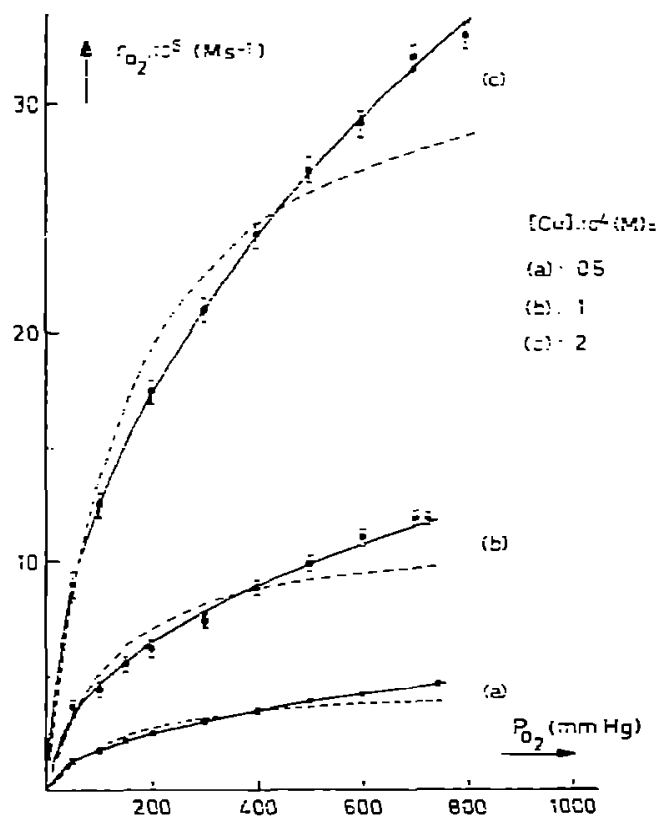

Fig. 3. The rate of cxygen consumption ( $\left.r_{O_{2}}\right)$ as a function of the oxygen pressure $\left(P_{o_{2}}\right)$. Experimental data are given with their standard deviations. Dashed lines are best fits according to eqn. (4) (Michaelis-Menten) and to eqn. (5), respectively. [cysteine] $]_{0}=$ $1.74 \times 10^{-1} \mathrm{M} ;[\mathrm{NaOH}]=0.25 \mathrm{M}$.

TABLE 3

Kinetic constants concerning the oxygen consumption

\begin{tabular}{llllll}
\hline $\begin{array}{l}{[\mathrm{Cu}] \times 10^{4}} \\
\left(\mathrm{~mol} 1^{-1}\right)\end{array}$ & $A^{*}$ & $B *$ & $k_{1} * *$ & $x * *$ & $k_{2} * * *$ \\
\hline 0.5 & 0.219 & 28.9 & 0.206 & 0.47 & 0.171 \\
1.0 & 0.088 & 10.6 & 0.548 & 0.47 & 0.439 \\
2.0 & 0.030 & 4.34 & 1.400 & 0.48 & 1.18 \\
\hline
\end{tabular}

*Equation (4).

**Equation (5).

$* *$ Equation (6).

Order with respect to copper

The order with respect to copper proved to be variable, increasing from 1.02 at $[\mathrm{Cu}]=1.25 \times 10^{-5} \mathrm{M}$ to 1.56 at $[\mathrm{Cu}]=4 \times 10^{-4} \mathrm{M}$. This fact suggests that the kinetics with respect to copper is composed of a combination of a first and a second order term:

$$
r_{o_{2}}=R[\mathrm{Cu}]+S[\mathrm{Cu}]^{2} \text {. }
$$




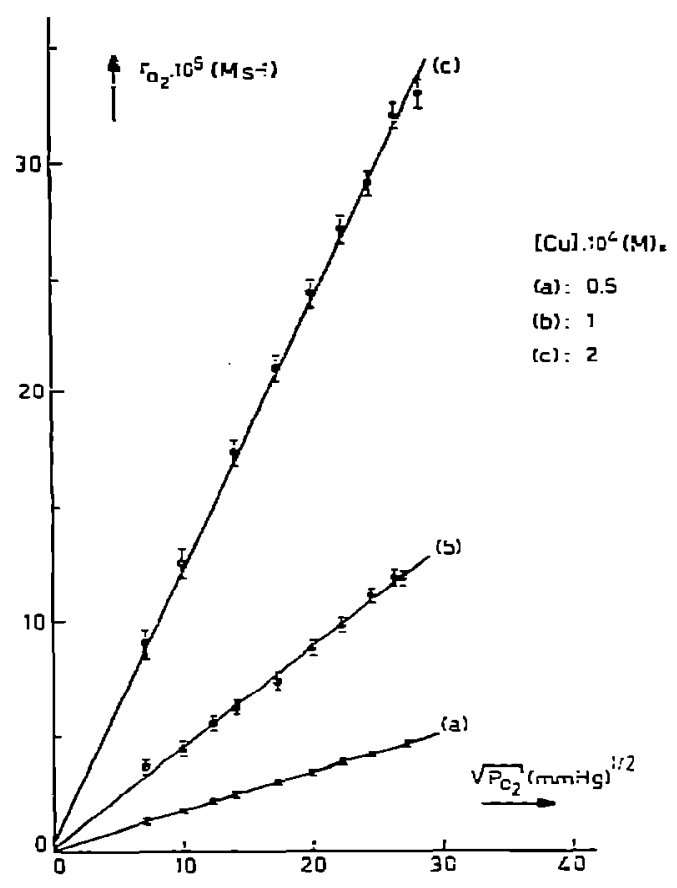

Fig. 4. The rate of oxygen consumption $\left(r_{\mathrm{O}_{2}}\right)$ as a function of $\left(P_{\mathrm{O}_{2}}\right)^{05}$. Experimental data are given with their standard deviations. Lines are best fits according to $\mathrm{r}_{2}=a+$ $k_{2}\left(P_{0}\right)^{05} ; a$ is neglectable within the limits of accuracy. Same experimental conditions as in Fig. 3.

Rearrangement of this expression gives:

$$
r_{o_{2}} /[\mathrm{Cu}]=R+S[\mathrm{Cu}] \text {. }
$$

It is shown in Fig. 5 that the experimental data obey the linear expression (8), with $R=7.8 \times 10^{-2} \mathrm{~s}^{-1}$ and $S=4.2 \times 10^{2} \mathrm{~mol}^{-1} 1 \mathrm{~s}^{-1}$. The values of $R$ and $S$ are obtained for $P_{\mathrm{O}_{2}}=760 \mathrm{~mm}$ Fg corresponding to $\left[\mathrm{O}_{2}\right]=$ $1.25 \times 10^{-3} \mathrm{~mol} \mathrm{l}^{-1}$.

Combination of the kinetic results leads to the following overall kinetic expression for the copper catalysed autoxidation of cysteine in alkaline medium:

$$
r_{\mathrm{O}_{2}}=k_{\mathrm{I}}\left[\mathrm{O}_{2}\right]^{0.5}[\mathrm{Cu}]+k_{\mathrm{II}}\left[\mathrm{O}_{2}\right]^{0.5}[\mathrm{Cu}]^{2} \text {. }
$$

The values of $k_{\mathrm{I}}$ and $k_{\mathrm{I}}$ were calculated from those of $R$ and $S$, respectively, leading to $k_{\mathrm{I}}=2.21 \mathrm{~mol}^{-0.5} \mathrm{1}^{0.5} \mathrm{~s}^{-1}$ and $k_{\mathrm{m}}=1.19 \times 10^{4} \mathrm{~mol}^{-1.5} \mathrm{l}^{1.5} \mathrm{~s}^{-1}$.

\section{Discussion}

The liquid state es.r. spectrum with nitrogen hyperfine splitting as shown in Fig. 2 is similar to that reported by Hanaki [15] for the copper 


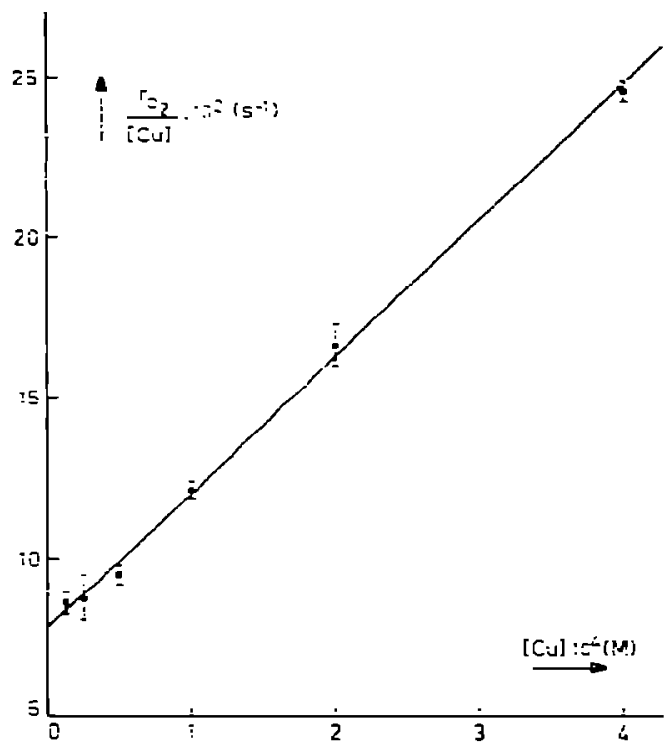

Fig. 5. $r_{\mathrm{O}_{2}} /[\mathrm{Cu}]$ as $a$ function of $[\mathrm{Cu}]$. The solid line is a best fit according to eqn. (8).

catalysed oxidation of cysteine at $\mathrm{pH}=7.5$. Due to tre complicated pattern of hyperfine splitting the precise number of cysteine ligands bonded to $\mathrm{Cu}$ (II) remains uncertain. In accordance with ideas of Cavaliini et al. [3] and Blumberg et al. [20] a $\mathrm{Cu}^{\mathrm{II}}\left(\mathrm{RS}^{-}\right)_{2}$ complez seems quite probable. However, the presence of copper complexes containing more than two ligands cannot be ruled out. The latter complexer wrere already postulated previously to account for the effect of the cys eine concentration on the rate of production of $\mathrm{H}_{2} \mathrm{O}_{2}$ [14].

From the intensity of es.r. spectra obtained from frozen samples, Cavallini et al. [3] calculated the concentration of copper(II) to be only $\mathbf{8 0 \%}$ of the added copper. However, the inaccuracy of their method did not permit definitive conclusions to be drawn. Our results show a $\mathrm{Cu}$ (II) intensity which accounts for at least $98 \%$ of the added copper, indicating that only $2 \%$ of the total amount of copper might be present in different valence states or structures [21] during the catalytic oxidation of cysteine. The low level of any Cu(I) complex, if present, is completely consistent with our previocus work [14], in which it was found that $\mathrm{Cu}(\mathrm{I})$ generated under anaerobic conditions has a remarkable catalytic effect upon the reacticn between cysteine and $\mathrm{H}_{2} \mathrm{O}_{2}$. The absence of a catalytic effect for this particular reaction under oxygen atmosphere during the autoxidation already pointed to a very low level of $\mathrm{Cu}(\mathrm{I})$ under those conditions.

However, a low level of $\mathrm{Cu}(\mathrm{I})$ does not exclude a Cu(II)/Cu(i) redox couple with a relatively fast reoxidation step being operative. Therefore, the feasibility of a $\mathrm{Cu}(\mathrm{II}) / \mathrm{Cu}(\mathrm{I})$ redox couple has been investigated in more 
detail. The study of the kinetics of the reduction process during reaction conditions relevant to the catalytic process leads to a rate which is second order with respect to copper and zero order with respect to cysteine $\left(k_{\text {an }}=\right.$ $55 \pm 2 \mathrm{~mol}^{-1} \mathrm{is}^{-1}$ ). It should be noted that Cavallini (3] has already investigated the anaerobic reduction, but the numerical value reported for the rate constant was not necessarily valid for the wide range of cysteine and copper concentrations as is required for our work.

The hypothesis of a $\mathrm{Cu}(\mathrm{II}) / \mathrm{Cu}(\mathrm{I})$ redox couple in the catalytic oxidation can now be verified by comparing the rate of oxygen consumption during the catalytic reaction with the rate of reduction of the Cu(II) complex under anaerobic conditions. In view of this, one should note that the involvement of a redox couple implies that during steady state the rate of reduction of Cu(II) must be equal to the rate of reoxidation:

$$
\left(-\frac{\mathrm{d}\left[\mathrm{Cu}^{\mathrm{II}}\right]}{\mathrm{d} t}\right)_{\mathrm{red} .}=\left(-\frac{\mathrm{d}\left[\mathrm{Cu}^{\mathrm{I}}\right]}{\mathrm{d} t}\right)_{\mathrm{reax} .} .
$$

Suppose, as is accepted in the literature [ $1-7]$, that oxygen is only utilized for the reoxidation of $\mathrm{Cu}(\mathrm{I})$, then the rate of reoxidation can be related to the rate of oxygen consumption during the catalytic reaction by :

$$
\left(-\frac{d\left[\mathrm{Cu}^{\mathrm{I}}\right]}{\mathrm{d} t}\right)_{\mathrm{rovx} .}=2 r_{\mathrm{O}_{2}}
$$

(oxygen acting as a 2 electron acceptor).

Combining eqns. (10) and (11) leads to

$$
\left(-\frac{d\left[\mathrm{Cu}^{\mathrm{II}}\right]}{\mathrm{d} t}\right)_{\text {red. }}=2 r_{\mathrm{O}_{2}} \text {. }
$$

in Table 4 the rate of reduction (left side of eqn. (12)) has been compared with the actual rate of oxygen consumption. It can be seen that in all cases the oxygen consumption rate is much Iarg $r$ than it should be according to eqn. (12). Consequently, only a minor part of the oxygen might be consumed in a $\mathrm{Cu}^{\mathrm{II}} / \mathrm{Cu}^{\mathrm{I}}$ redox cycle during the catalytic reaction, and a much faster pathway has to be available for the electron transfer reaction.

The observed half order with respect to oxygen, points to a chain like process. Well known examples of these types of process ar free radical reactions occurring in the gas phase [221. A chain like process in the liquid state has been proposed by Jameson et al. [23, 24] for the copper catalysed oxidation of ascorbic acid. To account for the half order with respect to oxygen, they assumed a propagation reaction proceeding via free ascarbate radicals. The authors suggested that their model was applicable to systems containing nitrogen and sulphur donor ligands. However, the hypothesis of both free ascorbateradicals and free thiyl radicals during the catalytic process is not supported by experimental evidence. Moreover, as shown previously [14], the high selectivity of the conversion of cysteine into 
TABEE 4

Comparisen of the rate of reduction of the Cu(II)-cysieine complex and the reie of oxygen consumption according to equ. (12)

\begin{tabular}{lll}
\hline $\begin{array}{l}{[\mathrm{Cu}] \times 10^{4}} \\
\left(\mathrm{~mol} \mathrm{l} \mathrm{l}^{-1}\right)\end{array}$ & {$\left[-\frac{\mathrm{d}[\mathrm{Cu}(\text { II) })}{\mathrm{d} t}\right]_{\mathrm{red}}$} & $2 \times \mathrm{rO}^{* *}$ \\
& $\times 10^{7}\left(\mathrm{~mol} \mathrm{l}^{-1} \mathrm{~s}^{-1}\right)$ & \\
\hline 0.5 & 1.4 & 94 \\
1 & 5.5 & 240 \\
2 & 22 & 540 \\
\hline
\end{tabular}

* $\left[-\frac{\mathrm{d}[\mathrm{Cu}(\mathrm{II})]}{\mathrm{d} t}\right]_{\mathrm{red}}=k_{3 \mathrm{n}}[\mathrm{Cu}]^{2}$ with $k_{m}$ obtained from Table 2.

* Values of $r_{\mathrm{O}_{2}}$ obtrined from Fig. $3\left(P_{\mathrm{O}_{2}}=760 \mathrm{mmHg}\right)$.

cystine can hardly be reconciled with a mechanism involving free thiyl radicals. These radicals would certainly lead to a variety of reactions with oxygen [25 - 27] learling to oxygen containing acidic products, which contrasts with our observation [14]. Otherwise a chain like propagation mechanism is not ne sessarily connected with free racicals. Therefore, alternative reaction models in which product formation proceeds within the catalytically active copper compiex also deserve attention.

In view of this the reaction model as proposed by Jameson $e t a l$. $[23,24]$ has been modified so that during the propagation cycle, intermediate RS- radicals remain bonded to the copper complez due to the reaction of RS- with $\mathrm{RS}^{-}$within the coordination sphere. This idea is supported by the well known fact that RS - has a high affinity towards RS leading to the formation of RŚSR [25, 28 - 30]. Hence, formation of coordinated $R \bar{S} \mathrm{SR}$ within the catalytically active complex would prevent the generation of free thiyl radicals in the solution.

The reaction model emerging from these ideas is depicted in Scheme 1. In accordance with the model of Janneson et al. $[23,24]$ initiation of the chain reaction is supposed to be accomplished through decomposition of an oxygen-bonded copper dimer [21]. In our concept the p:oduced complex, A, will be operative in the propagation cycle, which gives rise to product formation ( $\mathrm{HO}_{2}$ and $\mathrm{RSSR}$ ) via consecutive one-electron transfer. In complex B a one electron transfer seems to be likely, considering the high susceptibility of RSSR to oxidation [25, 31] and the stabilization of the $\mathrm{O}_{2}^{-}$ion radival by bonding to the copper-cysteine complex [32], resulting in complex $C$. An additional one electron transfer is then possible under the formation oi a more stable peroxide. Chain termination would be eifected via disproportionation of the superoxo colnplex, D. For Scheme 1 the kinetics cain be derived starting with the steady state conditions:

$$
k_{i}\left[\mathrm{Cu}^{\mathrm{C}}\left(\mathrm{RS}_{\mathrm{R}}^{\mathrm{R}}-1\right]^{2}\left[\mathrm{O}_{2}\right]=k_{\mathrm{t}}[\mathrm{D}]^{2}\right. \text {. }
$$




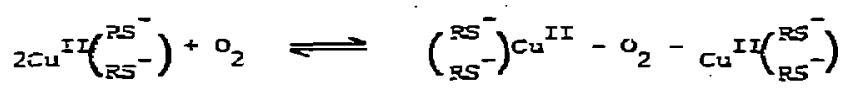

Initietion:





Terfination:



Scinere 1

The following relation holds for the propagation cycle:

$$
k_{\mathrm{D}}[\mathrm{D}]=k_{\mathrm{A}}[\mathrm{A}]\left[\mathrm{O}_{2}\right] \text {. }
$$

Combination of eqns. (13) and (14) leads to:

$$
[\mathrm{A}]=\frac{k_{\mathrm{D}}}{k_{\mathrm{A}}} \cdot\left(\frac{k_{\mathrm{i}}}{k_{\mathrm{t}}}\right)^{0.5} \cdot\left[\mathrm{Cu}^{\mathrm{I}}\left(\mathrm{RS}^{-}\right)\right] \cdot\left[\mathrm{O}_{2}\right]^{-0.5} \text {. }
$$

The rate of oxygen consumption in the propagation cycle is:

$$
r_{\mathrm{O}_{2}}=k_{\mathrm{A}}[\mathrm{A}]\left[\mathrm{O}_{2}\right] \text { : }
$$

Making use of eqn. (15) gives: 


$$
r_{\mathrm{O}_{2}}=k_{\mathrm{I}}\left[\mathrm{Cu}^{\mathrm{U}}\left(\mathrm{RSS}_{\mathrm{RS}}^{-}\right)\right]\left[\mathrm{O}_{2}\right]^{0.5}=k_{\mathrm{I}}[\mathrm{Cu}]\left[\mathrm{O}_{2}\right]^{0.5}
$$

Expression (17) accounts for the first order term in copper of the experimentally found kinetic expression (9).

To find a second order term with respect to copper an alternative reaction path for complex $D$ should be considered (see Scheme 2). Reaction of this complex with the $\mathrm{Cu}^{\mathrm{II}}\left(\mathrm{RS}^{-}\right)_{2}$ species, which has been proved to be abundantly present in the reaction system might lead viz an intermolecular electron teansfer to complex $\mathbf{E}$. Taking the initiation and termination processes as for Scheme 1 and making use of the steady state condition:

$$
\left.k_{\mathrm{D}} \cdot \mathrm{DD}\right]\left[\mathrm{Cu}^{\mathrm{II}}\left(\mathrm{RS}_{\mathrm{RS}}^{-}\right)\right]=k_{\mathrm{E}}[\mathrm{E}]\left[\mathrm{O}_{2}\right],
$$

one can derive for the rate of oxygen consumption:

$$
r_{\mathrm{O}_{2}}=k_{\mathrm{II}}[\mathrm{Cu}]^{2}\left[\mathrm{O}_{2}\right]^{0.5} \text {. }
$$

Expression (19) represents the second order term with respect to copper of the kinetic expression (9).

The foregoing discussion and the experimentally found kinetic data indicate that the copper catalysed autoxidation of cysteine in alkaline

Propagation:
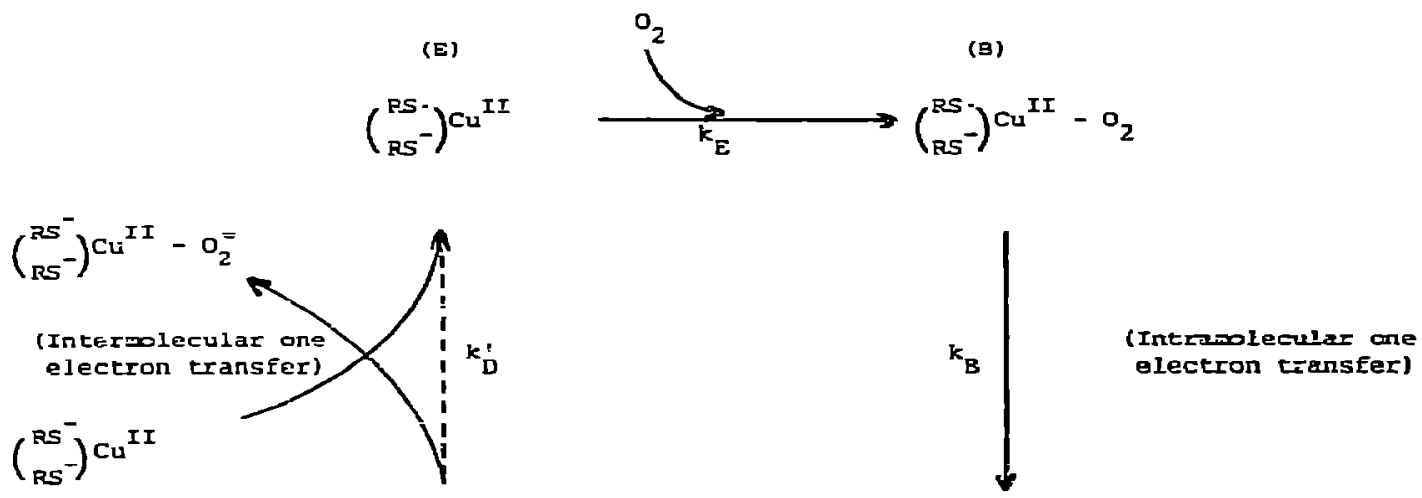

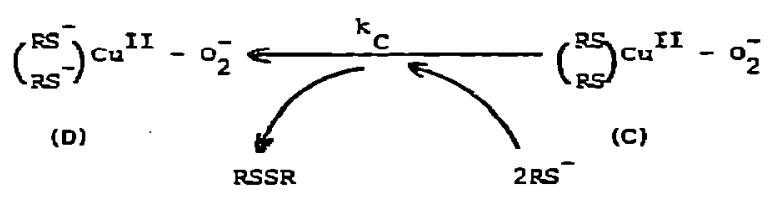


medium can be represented by a model consisting of two reaction pathways, as depicted in Schemes $I$ and 2, respectively, being concurrently operative. It should be recognized that the identity of the copper species that is suggested to occur in the proposed reaction model is not established and needs further investigation. As to the various types of copper(E)dioxygen complezes, as proposed in Schemes 1 and 2 , one might wonder why any influence of oxygen upon the signal of the copper(II)-dicysteine complex, measured both with e.s.r. and u.v. spectroscopy, was not detected. However, it should be noted that chain reactions usually proceed via a very low amount of chain carriers. Therefore, the amount of copper species involved in the reaction sequence will probably be relatively low, leading to undetectable alterations of the overall signal with aeration.

The generation of $\mathrm{H}_{2} \mathrm{O}_{2}$ during the catalytic process, as suggested in thie proposed reaction model, is in accordance with our earier reported results [14]. The model presented does not account for the complete reduction of dioxygen into water at the catalytic site. This process was found to be of minor importance, but it increased progressively on using higher concentrations of cysteine. This feature was ascribed to the formation of copper complexes containing more than two cysteinate ligands. Further experimental evidence is required to obtain more insight into this question.

The reasons for introducing a binuclear oxygen complex are derived from the analogy of our system with the copper containing proteins. The active species in the latter systems generally consist of clusters containing two copper ions bonded to cysteire ligands. The valence state of copper in these clusters is usually assumed to be Cu(I). However, there are indications that Cu(II) clusters also are able to bind dioxygen and promote electron transfer from the liganois towards the dioxygen [33, 34]. Bettelheim et al. [32] reported relatively high rates of oxygen reduction when using dimeric Cu(II) complezes as a catalyst for cathodic reduction in aqueous solutions.

A model containing catalytically active $\mathrm{Cu}^{\mathrm{I}}-\mathrm{O}_{2}$ complexes with a concentration below the limits of accuracy $(<2 \%$ ) of the Cu(i) e.sr. intensity measurements also deserves attention. It should be stressed that such a $\mathrm{Cu}_{1}^{\mathrm{I}}-\mathrm{O}_{2}$ complex, active in a propagation cycle, represents in fact a modified $\mathrm{Cu}(\mathrm{II}) / \mathrm{Cu}(\mathrm{I})$ redox cycle. The initiation reaction could then be represented by reaction (4), i.e., the anaerobic reduction of the $\mathrm{Cu}(\mathrm{II})-$ dicysteine complex. After complexing with oxygen the Cu(I) species might then generate the oxidation products in the propagation cycle. In view of the low rate of the initiation reaction (reaction (4)), a mechanism proceeding vir a $\mathrm{Cu}(\mathrm{I})-\mathrm{O}_{2}$ complex may be relevant, only provided that complexing witk oxygen is feasible without the concurrent formation of Cu(II), leading to ìermination of the chain reaction. The validity of such a mechanism has been checked by carrying out oxygen pulse experiments into the reduced catalytic system. It was found that axygen was not consumed in a propagation cycle but only utilized for the reoxidation of $\mathrm{Cu}(\mathrm{I})$. Therefore, the occurrence of a catalytically active $\mathrm{Cu}(\mathrm{I})-\mathrm{O}_{2}$ species can be excluded. 
The initiation reaction of the proposed reaction scheme has been interpreted as an electron transfer from the ligands to oxygen leaving the valence state of copper unchanged. Altematively, electron transfer irom copper to oxygen has alsa to be considered. This would result in a propagation cycle involving a $\mathrm{Cu}$ (III) species. The formal valence state Cu(WI) would allow a two electron transfer from the thiolate arions to the copper ion, immediately resulting in disulfide fommation and $\mathrm{Cu}(\mathrm{I})$. However, as discussed above, it was found that reoxidation of $\mathrm{Cu}(\mathrm{E})$ regenerates the original $\mathrm{Cu}^{11}\left(\mathrm{RS}^{-}\right)_{2}$ complex, thus terminating the propagation cycle. The half order kinetics with respect to oxygen implies a chain reaction which is not ieasible with a $\mathrm{Cu}(\mathrm{IL}) / \mathrm{Cu}$ (I) redox system. A Cu(III) ion in the activated copper complexes mighi be present, but the essential features of the proposed mechanis n will not be affected.

In summery, the accuracy of the kinetic experiments carried out in a wide range of oxygen pressures, allows definite conclusions to be drawn conceming the order with regard to ozygen. This has been found to be the same as for the copper catalyzed oxidation of ascorbic acid. Jameson et al. $[23,24]$ introduced a propagation cycie proceeding via free ascorbate radicals, whereas, in this work, electron transfer via bonded radicals has been proposed. A decision as to the validity of either mechanism needs further experimental evidence. From this work the following characteristics concerning the mechanism of the copper catalyzed autoxidation of cysteine in alkaline medium have been obtained:

(i) The hypothesis of a simple $\mathrm{Cu}$ (II)/Cu(I) redox couple as given in the literature must be rejected.

(ii) A chein reaction with activated molecular copper species can account for the half order kinetics with respect to oxygen. The occurrence of free thiyl radicals in this chain reaction seems very unlikely considering the high selectivity of the exidation reaction.

(iii) Two types of reaction pathway are operative in the propagation cycle, leading to a first and second order reaction with regard to copper.

(iv) A formal valence state $\mathrm{Cu}(\mathrm{III})$ in the activated copper complexes preser.t in the propagation cycle cannot be ezcluded.

\section{Acknowledgements}

We thank ir. J. C. J. M. van der Cammen for performing some of the u.v. and e.s. measurements. The authors are indebted to Professor Dr G. C. A. Schuit and to Professor Dr R. Prins for their encouragement and critical reading of the manuscript.

\section{References}

1 T. J. Wallace, A. Schriesheim, H. Hurwitz and K. B. Glsser, Ind Eng. Chem., Frod. Res. Dev., 3 (1964) 237.

2 C. J. Swan and D. L. Trimm, J. Appl. Chem., 18 (1968) 340. 
3 D. Carallini, C. de Marco and S. Dupre, Arch. Biochem. Biophys., 124 (1968) 18.

4 D. Cavallini. Z. de Mareo, S. Dupré and G. Rotilio, Arch. Biochem. Biophys., 130 (1969) 354.

5 A. Hanali and H. Kemide, Chem. Pharm. Bull., I9 (1971) 1006.

6 A. Hanaki and H. Kamide, Chem. Pharm. Bull.; 21 (1973) 1421.

7 A. Hanaki and H. Kamide, Chem. Pharm. Butl., 23 (I975) 1671.

8 R. Malkin, in G. I. Eichhorn (ed.), Inorganic Biochemistry, Elsevier, Amsterdan, 1973, P. 689 .

9 A. R. Amundsen, J. Whelan and B. Bosnich, J. Am. Chem. Soc., 99 (1977) 6730.

10 J. H. Scheinberg and A. G. Morell, in G. I. Eichhorn (ed.), Inorganic Biochemistry, Elsevier, Amsterdam, IS73, p. 306.

11 W. Byers, G. Curzon, K. Garbett, B. E. Speyer, S. N. Young and R. J. P. Williams, Biochem. Biophys. Acta, 310 (1973) 38.

12 R. P. J. Willians, Pure Appl. Chem., 38 (1974) 249.

13 R. Lemberg and J. Barret, Cytochromes, Academic Press, New York, 1973.

14 J. Zwart, J. H. M. C. van Wolput, J. C. J. M. van der Cammen and D. C. Koningsberger, J. Mol. Catal., 11 (1981) 69.

15 A. Haneli, Chem. Pharm. Bull, 22 (1974) 2491.

16 H. MicConnell, J. Chem. Phys., 25 (1956) 709.

17 J. ten Bosch, Ph. D. Thesis, Univ. Utrecht, The Netherlands, 1967.

18 M. L. Randolph, in H. M. Swartz, J. R. Bolton and D. C. Borg (eds.), Biological Applications of Electron Spin Resonance, Wiley-Interscience, New York, 1972, p. 119.

19 S. J. Wyard, $J$. Sci. Instrum., 42 (1965) 769.

20 W. E. Blumbers and J. Peisach, J. Chem. Phys., 49 (1968) 1973.

21 T. D. Smith and J. R. Pilbrow, Coord. Chem. Rev., 13 (1974) 173.

22 K. J. Laîdler, Reaction Kinetics, Vol. 1, Pergamon, London, 1963.

23 R. F. Jameson and N. J. Blackbum, J. Chem. Soc., Dalton, Trans., (1976) 534.

24 R. F. Jameson and N. J. Blackburn, J. Chem. Sac., Dalton Trars., (1976) 1597.

25 W. S. Lin, M. Lel, G. M. Gaucher and D. A. Armstrong, Discuss. Faraday Soc., 63 (1977) 226 .

26 M. Lal, Radiat. Eff., 22 (1974) 257:

27 M. Lal, Car. J. Chem., 54 (1976) 1092.

28 M. Simic and M. Z. Hofiman, J. Am. Chem. Sac., 92 (1970) 6096.

29 G. Caspari and A. Granzow, J. Phys. Chem., 74 (1977) 836.

30 G. E. Adams, G. S. McNaughton and B. D. Michael, Trans. Faraday Soc., 64 (1968) 902.

31 J. P. Barton and J. F. Packer, Int. J. Radiat. Phys. Chem., 2 (1970) 159.

32 J. Stauff and F. Ninmerfeil, $Z$. Naturforsch., 246 (1969) 1015.

33 A. Bettelheim, M. Faraggi, I. Hodara and J. Menassen, J. Chem. Soc. Faraday Trans. l, 73 (1977) 582 .

34 R. Malkin and B. G. Malmström, Adv. Enzymol., 33 (1970) 177. 